of land ownership, as well as an obligation not to use the property to the detriment of a human and society. Such legal regulation of the constitutional right of land ownership in comparison with the constitutions of many countries of the world is more detailed, which is directly related to the importance of land for the national economy and national security. The similar legal regulation is partially observed in the constitutions of most post-Soviet states, where land occupies a prominent place in the constitutional regulation. Art. 14 of the Constitution of Ukraine develops the basic provisions enshrined in Art. 13 of the Main Law. It determines the structure of land legislation and establishes the basic principles of regulation of land relations in modern conditions and in the future. It also defines the legal regime of one of the most important natural resources - land, which is recognized as the main national wealth, which is under special protection of the state. Issues of land ownership should be regulated exclusively by laws as acts of higher legal force, adopted by the Verkhovna Rada of Ukraine in accordance with the established procedure.

Key words: Constitution of Ukraine, property right, land ownership.

УДК 343.43

DOI https://doi.org/10.32782/2409-4544/2019-2/25

Д. Фелонюк

\title{
Адміністративно-правові механізми протидії торгівлі людьми в контексті захисту прав і свобод громадян України за кордоном
}

Проаналізовано національний механізм взаємодії суб'єктів, які здійснюють заходи щодо захисту прав та свобод громадян України за кордоном. Розглядаються особливості застосування поняття «торгівля людьми» в праві. Досліджуються масштабність проблеми і напрямки їі вирішення 3 урахуванням європейського досвіду. Звертається увага на необхідність тісної координації дій вітчизняних і міжнародних організацій щодо попередження та захисту громадян України від торгівлі людьми, боротьбою зі злочинністю пов'язаної з цими протиправними діями. Зроблено висновок, що національний адміністративно-правовий механізм протидії торгівлі людьми передбачає систему заходів, спрямованих на виявлення злочину торгівлі людьми, встановлення осіб, причетних до його скоєння і притягнення їх до відповідальності. Ефективність даного механізму залежить в значній мірі від взаємодії і координації дій між національними та міжнародними інститутами, сферою яких $\epsilon$ торгівля людьми. Цьому буде сприяти інтеграція українського законодавства до європейського а також співробітництво як державних так і недержавних суб'єктів, які здійснюють заходи у сфері протидії торгівлі людьми. Потребують узгоджених міждержавних дій процедури екстрадиції жертв торгівлі людьми, так як більшість справ завершується здебільшого їхнім арештом та депортацією. Відчувається брак висококваліфікованих працівників у системі правоохоронних органів, міграційних служб та інших установ, до компетенції яких належить протидія торгівлі людьми і надання допомоги потерпілим від цього злочину. Більш результативною в цьому плані є співпраця міжнародних правозахисних організацій та засобів масової інформації.

Ключові слова: торгівля людьми, права, свободи, громадянин, Україна.

Постановка наукової проблеми та її значення. В Конституції України закріплено право на життя, свободу, вільне пересування, особисту недоторканність, свободу праці та іншу не заборонену законом діяльність. Також громадянам України гарантується можливість вибору місця перебування і проживання в тому числі і за кордоном. Щодня тисячі наших співвітчизників перетинають кордон $\mathrm{i}$ тим потрапляють в правове поле іноземної держави. Одними 3 причин еміграції є можливість лікування, отримання освіти, роботи.

В останній період досить інтенсивно відбувається трудова еміграція, яка зумовлена з одного боку непростою соціально-економічною ситуацією в країні, а з іншого боку лібералізацією візового режиму з СС. За результатами репрезентативного опитування населення, здійсненого на замовлення Міжнародної організації з міграції (МОМ) в 2015 р., частка тих, хто працює за кордоном неофіційно, становить близько $41 \%$ від усіх громадян України, які працюють за кордоном [1]. Більшість 3 них

() Фелонюк Д., 2019 
виїжджають за приватними чи туристичними візами, працюють без необхідних документів, що істотно зменшує їх правовий захист та стає причиною потрапляння у сферу інтересів суб'єктів торгівлі людьми. Тому важливим завданням держави є гарантування та захист прав та свобод наших співвітчизників за кордоном, що і актуалізує наше дослідження.

Аналіз досліджень проблеми. Тематиці протидії торгівлі людьми присвятили свої праці такі вчені, як М. Буряк, Є. Євстіфеєва, С. Метєлєва. Аналіз державної політики у цій сфері став об'єктом досліджень С. Бородіна, Л. Галенської, К. Левченко, В. Панова. Окремі аспекти проблеми висвітлено працях Н. Лукач, Г. Жуковської. Практичні сторони проблеми захисту прав громадян України за кордоном досліджували Н. Павловська, Б. Стахура. Однак, в даних працях недостатньо повно висвітлено питання формування ефективних адміністративних інструментів щодо протидії торгівлі людьми стосовно громадян України за кордоном.

Мета статті полягає у тому, що на основі чинного законодавства України та практики його реалізації здійснити аналіз адміністративно-правового механізму протидії торгівлі людьми в аспекті забезпечення прав та свобод громадян України за кордоном.

Завданнями цієї статті є розглянути нормативно-правову базу діяльності суб'єктів у сфері протидії торгівлі людьми, проаналізувати вітчизняний механізм протидії торгівлі людьми; окреслити напрямки підвищення ефективності даного механізму з врахуванням міжнародного досвіду.

Виклад основного матеріалу й обгрунтування отриманих результатів дослідження. Одним із найбільш серйозних порушень фундаментальних прав людини $\epsilon$ торгівля людьми. Вона руйнує принцип рівної гідності всіх людей та нівелює верховенство права. Дана проблема набуває міждержавного характеру і постійно перебуває в цетрі уваги міжнародної спільноти. Щодо України, то за оцінками Представництва Міжнародної організації з міграції (МОМ), від торгівлі людьми, починаючи з 1991 р., постраждали понад 160 тис. українців [2, с. 1]. Зокрема, в Україні починаючи 3 2012 року по 2017 р. встановлено статус для 776 осіб, які постраждали від торгівлі людьми. 3 них жінки - 308 осіб, чоловіки - 389, хлопчики - 29, дівчатка - 50. Якщо говорити про види експлуатації, то це трудова експлуатація - 413 осіб, сексуальна - 200 осіб, жебрацтво - 56 осіб, втягнення в злочинну діяльність - 65 [3]. Відмітимо, що з 2016 р. торгівля людьми починає стрімкими темпами зростати.

Торгівлю людьми можна назвати одним 3 найтяжчих злочинів проти особи. Комісія ООН 3 питань боротьби 3 міжнародною злочинністю розглядає ії як третій за своїми масштабами вид організованої злочинності, котра поступається лише нелегальній торгівлі наркотиками та зброєю. За даними Комісії, щорічно прибутки такого транснаціонального бізнесу становлять 12 млрд дол. США [4 c. 10]. 15 листопада 2000 р. Комісією з прав людини ООН торгівлю людьми визнано сучасною формою рабства. В прийнятій Генеральною Асамблеєю ООН Резолюції 55/25 міститься Протокол про попередження і припинення торгівлі людьми, особливо жінками та дітьми. В документі також визначено покарання за неї, що доповнює Конвенцію ООН проти транснаціональної організованої злочинності. В Протоколі вперше дається міжнародне визначення поняття «торгівля людьми». Торгівля людьми - це здійснювані з метою експлуатації вербування, переміщення, передача, переховування або одержання людей шляхом загрози силою чи ії застосування або інших форм примусу, викрадення, шахрайства, обману, зловживання владою або уразливістю становища, або шляхом підкупу, у вигляді платежів чи вигод, для одержання згоди особи, яка контролює іншу особу. Експлуатація включає різні форми сексуальної експлуатації, примусову працю або послуги, рабство або звичаї, подібні до рабства, підневільний стан або вилучення органів (стаття 3(а) Протоколу) [5]. При цьому якщо стосовно жертви торгівлі людьми було використано будь-який із зазначених заходів впливу, то ії згода на заплановану експлуатацію не береться до уваги.

Стосовно форм торгівлі людьми, то всіх їх можна звести до наступних: 3 метою сексуальної експлуатації; трудової експлуатації, використання у жебракуванні, виготовленні порнопродукції, вилучення органів та ін. Особливо актуальною для наших громадян є трудова експлуатація. Постраждалі зазвичай працюють на надважких роботах із цілковитим порушенням техніки безпеки праці, що сприяє росту травматизму та трагічних випадків. Часто в таких осіб забирають документи i вони повністю ізольовані, не маючи можливості звернутися до українських дипломатичних та консульських установ з метою захисту їх прав та свобод.

Щодо причин торгівлі людьми, то їх можна поділити на зовнішні та внутрішні. До зовнішніх належать недієва система протидії торгівлі людьми у світі; невідповідність міжнародної нормативноправової бази в сфері попередження торгівлі людьми та захисту потерпілих осіб реальним умовам; попит на торгівлю людьми; наявність сприятливих умов для торгівців людьми. Відчутним також $\epsilon$ недостатня розробленість механізмів реалізації законодавчих положень; корумпованість 
відповідальних органів, які забезпечують дотримання законності; неузгодженість міграційної політики та реалій ринку праці в країнах. До внутрішніх передумов відносять економічні (наявність тіньової економіки; економічна нестабільність у державі; деформація у сфері розподілу благ; порушення принципів соціальної справедливості; соціальні (склад сім'ї - багатодітність, розлучення; стосунки в сім'ї - відсутність батьківської опіки над дітьми, наявність насильства в сім’і); психологічні (девальвація моральних цінностей значної частини населення та їхня деформація; інформаційні (погана обізнаність українських громадян щодо можливостей працевлаштування та перебування за кордоном та їх наслідки [4, с. 12].

Характерно, що вітчизняне законодавство не закріплює поняття зовнішньої (з перетином державного кордону) та внутрішньої (без перетину державного кордону) торгівлі людьми. Відповідно, торгівля людьми вважається злочином, котрий учинений як при перетині державного кордону, так і без цього. Зокрема в статті 149, п.1 Кримінального кодексу України зазначається, що «торгівля людиною, а так само вербування, переміщення, переховування, передача або одержання людини, вчинені з метою експлуатації, з використанням примусу, викрадення, обману, шантажу, матеріальної чи іншої залежності потерпілого, його уразливого стану або підкупу третьої особи, яка контролює потерпілого, для отримання згоди на його експлуатацію, караються позбавленням волі на строк від трьох до восьми років [6].

Поняття «торгівлі людьми» а також організаційно-правові засади протидії цьому явищу визначаються у Законі України «Про протидію торгівлі людьми» від 10 листопада 2015 р. № 766-VIII [7] (далі - Закон). Закон також містить основні напрями державної політики та засади міжнародного співробітництва у цій сфері, порядок встановлення статусу осіб, які постраждали від торгівлі людьми за кордоном, та порядок надання допомоги таким особам, повноваження органів виконавчої влади.

В Законі боротьба з торгівлею людьми розглядається як система заходів, спрямованих на виявлення злочину торгівлі людьми, у тому числі незакінченого, осіб, які від цього постраждали, встановлення фізичних/юридичних осіб - торгівців людьми та притягнення їх до відповідальності (п.1 ст.1) [7].

Значна увага в Законі України «Про протидію торгівлі людьми» приділена системі заходів, спрямованих на виявлення та усунення причин і умов, що призводять до торгівлі людьми а також на подолання торгівлі людьми шляхом іiї попередження і боротьби з нею та надання допомоги і захисту особам, які постраждали від таких дій.

Основними напрямами державної політики щодо попередження торгівлі людьми $є$ підвищення рівня обізнаності населення, превентивна робота, зниження рівня вразливості населення, подолання попиту. Боротьба із такого виду злочинністю має здійснюватися шляхом виявлення злочинів торгівлі людьми, осіб, причетних до скоєння злочину, притягнення їх до відповідальності (п.2 ст. 4) [7]. Держава також має надавати допомогу та захищати осіб, котрі постраждали від торгівлі людьми. Така політика передбачає удосконалення системи відновлення їхніх прав, надання комплексу послуг, впровадження механізму взаємодії суб' єктів у сфері протидії торгівлі людьми.

Закон окремо не виділяє суб' єктів, які здійснюють заходи у сфері протидії торгівлі людьми у випадку громадян України, що перебувають за кордоном. Загалом до таких суб'єктів згідно Ст. 5 Закону відноситься Президент України; Кабінет Міністрів України; центральні органи виконавчої влади; місцеві органи виконавчої влади; закордонні дипломатичні установи України; заклади допомоги особам, які постраждали від торгівлі людьми. Окрім них протидією торгівлі людьми в межах своєї компетентності займаються такі інституції як Міністерство соціальної політики, Міжвідомча рада з питань сім'ї, гендерної рівності, Державний департамент з усиновлення та захисту прав дитини, Міністерство внутрішніх справ України, Служба безпеки України, Генеральна прокуратура України, Верховний Суд України та судова система та ін. До функцій Кабінету Міністрів України, зокрема, належить спрямування та координація роботи суб' єктів, які здійснюють заходи у сфері протидії торгівлі людьми. Цей орган виконавчої влади затверджує Державну цільову програму у сфері протидії торгівлі людьми та здійснює контроль за їі реалізацією.

Роль центральних органів виконавчої влади $є$ швидше координуючою. На них, відповідно до визначених в установленому порядку у сфері протидії торгівлі людьми, покладено завдання формування та реалізації державної політики у цій сфері. Стосовно захисту громадян України які перебувають за кордоном ці владні суб'єкти наділені повноваженнями попередження, виявлення та розкриття злочинів торгівлі людьми, у тому числі тих, що мають характер транснаціональної організованої злочинності. В цьому плані важливою $є$ Стаття 7 Закону згідно якої центральні органи виконавчої влади здійснюють заходи щодо розшуку осіб, які переховуються від органів досудового розслідування і суду, ухиляються від виконання кримінального покарання за вчинення злочинів 
торгівлі людьми. В даному випадку йдеться про злочинців, які перебувають як на території України так і за кордоном.

Компетенції органів місцевого самоврядування зводяться в основному до забезпечення впровадження та функціонування Національного механізму взаємодії суб'єктів, які здійснюють заходи у сфері протидії торгівлі людьми. Їх функції $\epsilon$ швидше інформаційні а дії спрямовані переважно на запобігання торгівлі людьми через просвітницьку діяльність. Стосовно громадян, які перебувають за кордоном та постраждали від торгівлі людьми, такі органи беруть участь у роботі щодо встановлення статусу відповідної особи.

Захист прав та свобод громадян України, які перебувають за кордоном у сфері протидії торгівлі людьми здійснюється у тісному зв'язку з міжнародними правовими та політичними інституціями. Так згідно п. 1 ст. 28 Закону Україна бере участь у міжнародному співробітництві у сфері протидії торгівлі людьми на державному, регіональному та місцевому рівнях. Суб' єкти, що здійснюють заходи у сфері протидії торгівлі людьми, мають право укладення відповідних договорів про співробітництво, встановлення прямих зв'язків з відповідними органами іноземних держав, міжнародними організаціями згідно із законодавством України. Асоційоване членство України в СС дозволяє більш тісніше скоординовувати зусилля з міжнародними європейськими правозахисними структурами. В цьому плані важливим є здійснення імплементації вітчизняного законодавства у відповідності до європейських правових норм. Відзначимо, що в Європейському Союзі ефективно діє інституційний механізм щодо протидії торгівлі людьми. Він покликаний реалізовувати цінності $€ С$, втілювати його цілі, слугувати його інтересам, а також інтересам громадян держав-членів, забезпечувати послідовність, ефективність і наступність його політики і дій. Даний механізм має складну конструкцію. В основі його організаційної структури виступає Європейський Парламент, Європейська Рада, Європейська Комісія, Рада ЄС, Європейський координатор з протидії торгівлі людьми, Група експертів ЄС щодо торгівлі людьми, Свроюст, Європол, Європейська судова мережа, мережа Євроджаст.

До розробки та реалізації в Україні спільних міжнародних програм з питань протидії торгівлі людьми активно залучаються міжнародні правозахисні організації, співпрацю між якими координує $\mathrm{OOH}$. Все це сприяє узгодженню діяльності міжнародних та національних інституцій як державного так і недержавного рівня по виявленню та протидії торгівлі людьми.

В контексті нашого дослідження звернемо увагу, що значна роль у вирішенні даних питань відводиться дипломатичним та консульським установам. Зокрема, на них покладено завдання організації повернення в Україну громадян України, які постраждали від торгівлі людьми. В п. 1 ст. 18 Закону передбачено, що дипломатичні представництва та консульські установи України у разі необхідності забезпечують громадян України відповідними документами для повернення в Україну, надають необхідну консультаційну і правову допомогу та вживають необхідних заходів щодо їх повернення в Україну. У разі відсутності у постраждалих від торгівлі людьми громадян України коштів для повернення в Україну дипломатичні представництва та консульські установи України мають сприяти вирішенню цих питань та вжити заходи щодо поверненню їх в Україну [7].

Відзначимо, що дипломатичні та консульські служби досить активно ведуть інформаційну та роз'яснювальну роботу щодо попередження торгівлі людьми. Таке інформування є вкрай важливим для забезпечення належного реагування на факти вчинення злочинів у сфері торгівлі людьми проти українців за кордоном з метою захисту їхніх прав та інтересів, надання інформації для кримінального переслідування винних осіб, забезпечення безпеки постраждалих під час перебування за кордоном та їхнього безперешкодного повернення в Україну. В цьому контексті Міністерство закордонних справ України закликає громадян України, які потрапляють особисто або мають інформацію про потрапляння інших українських чи іноземних громадян у ситуацію, пов'язану з торгівлею людьми, негайно інформувати компетентні органи та українські дипломатичні установи. Відповідні звернення постійно поширюються через соціальні мережі.

Проте притягнення до кримінальної відповідальності суб'єктів торгівлі людьми за кордоном за національним законодавством є досить складним процесом. Це, зокрема, зумовлюється тим, що кримінальне законодавство багатьох країн не виокремлює торгівлю людьми як злочин і легалізує таку іiі форму, як, наприклад, проституція. Такими країнами $є$ Австрія, Німеччина, Греція, Нідерланди, Туреччина [8, с. 10]. По відношенню до інших країн ситуація не є оптимістичною. В одній з доповідей Державного департаменту США щодо торгівлі людьми зазначається, що «Україна $\epsilon$ країною походження, транзиту та поступово стає країною призначення для чоловіків, жінок і дітей, яких піддають примусовій праці та сексуальній експлуатації. Українці стають жертвами торгівлі людьми в Україні, а також у Росії, Польщі, Іраку, Іспанії, Туреччині, Кіпрі, в Сейшельській 
республіці, Португалії, Чеській республіці, Ізраїлі, Італії, Об'єднаних Арабських Еміратах, Чорногорії, Великобританії, Казахстані та Тунісі» [9]. Відповідно, правовими причинами торгівлі людьми є відсутність належної системи захисту потерпілих та недостатня захищеність українських громадян від «торгівців людьми» за межами країни.

Потребують узгоджених міждержавних дій процедури екстрадиції жертв торгівлі людьми, так як більшість справ завершується здебільшого їхнім арештом та депортацією. Відчувається брак висококваліфікованих працівників у системі правоохоронних органів, міграційних служб та інших установ, до компетенції яких належить протидія торгівлі людьми і надання допомоги потерпілим від цього злочину. Більш результативною в цьому плані $є$ співпраця міжнародних правозахисних організацій та ЗМІ. Це сприяє поширенню інформації про попередження таких злочинів та підвищенню поінформованості громадян про їхні права та свободи.

На фоні невисокої ефективності національного та міжнародного механізму захисту постраждалих від торгівлі людьми все більшої значимості набуває інститут омбудсмена, як захисника прав і свобод людини та громадянина на міждержавному рівні. Таку посаду в 1993 р. запроваджено в Європейському Союзі, а 31999 року цей інститут діє в Раді Європи. Основним його завданням є забезпечення рівності та справедливості всіх людей. Омбудсмени, зокрема, здійснюють діяльність що стосується протидії торгівлі людьми. В Україні таку функцію виконує Уповноважений Верховної Ради України з прав людини. Відмітимо, що Закон України «Про Уповноваженого Верховної Ради України 3 прав людини» від 02 жовтня 2018 р. № 2581-VIII значно розширює коло суб'єктів, що охороняються і на які може впливати обмудсмен. Правоохороні підлягають як ті, хто на законних підставах перебуває на території України, так і ті українські громадяни, які перебувають за ії межами [10]. В силу того, що інститут омбудсмена діє в більшості країн і в тому числі в України, то це дозволяє скоординовано протидіяти загрозам торгівлі людьми. Уповноважений Верховної Ради України з прав людини тісно співпрацює з Міжнародною організацією з міграції. Одним з результатів такої співпраці в 2017 р. стало повернення з Польщі до України двох громадян, які потерпали від того, що стали жертвами торгівлі людьми, проживаючи в нелюдських умовах та працюючи фактично за їжу [11, с. 37].

Висновки та перспективи подальшого дослідження. Таким чином, торгівля людьми $\epsilon$ серйозним порушенням прав та свобод громадян України, що перебувають за кордоном. Національний адміністративно-правовий механізм протидії торгівлі людьми передбачає систему заходів, спрямованих на виявлення злочину торгівлі людьми, встановлення осіб, причетних до його скоєння та притягнення їх до відповідальності.

Ефективність даного механізму залежить у значній мірі від взаємодії та координації дій між національними та міжнародними інституціями, сферою яких є торгівля людьми. Цьому сприятиме імплементація українського законодавства до європейського а також співпраця як державних так i недержавних суб’єктів, які здійснюють заходи у сфері протидії людьми.

\section{Джерела та література}

1. Новини прес-центру ООН [Електронний ресурc]. - Режим доступу: http://www.un.org.ua/ua/ informatsiinyi-tsentr/ news/ 3549-2015-07-30-14-43-47-ukrayinci-stayut-dedali-vrazli.

2. Жуковська Г. Взаємовідносини органів влади та громадськості у протидії торгівлі людьми: автореф. дис. на здобуття наук. ступеня. канд. наук з держ. управління / Г. Жуковська. - Київ, 2017. $20 \mathrm{c}$.

3. Федорович Н. Торгівля людьми: за статистикою найбільше українців експлуатують у Російській Федерації / Н. Федорович [Електронний ресурс]. - Режим доступу: URL: https://stopcor.org/torgivlyalyudmi-za-statistikoyu-naybilshe-ukrayintsiv-ekspluatuyut-u-rosiyskiy-federatsiyi-nataliya-fedorovich/.

4. Протидія торгівлі людьми в Україні: навчально-методичний посібник до спецкурсу / авториупорядники Е. Мручковська, Н. Пахом'юк, О. Кочерга; за заг. ред. К. Левківського та ін. - К.: ВАITE, 2017. $-88 \mathrm{c}$.

5. Протокол про попередження i припинення торгівлі людьми, особливо жінками i дітьми, i покарання за неї, що доповнює Конвенцію Організації Об’єднаних Націй проти транснаціональної організованої злочинності [Електронний ресурс]. - Режим доступу: http://zakon2.rada.gov.ua/ laws/show/995_791.

6. Кримінальний кодекс України України: Закон від 05. 04. 2001 р. № 2341-III [Електронний ресурс]. - Режим доступу: https://zakon.rada.gov.ua/laws/show/2341-14.

7. Про протидію торгівлі людьми: Закон України від 10 листопада 2015 р. № 766-VIII // Відомості Верховної Ради України. - 2015. - № 52. - Ст. 482. 
8. Лукач Н. Концептуальні засади та інституційні механізми протидії глобальній проблемі торгівлі людьми: автореф. дис. на здобуття наук. ступеня. канд. політ. наук / Н. Лукач. Чернівці, 2016. - 22 с. 9. Витяг із Доповіді Державного департаменту США про торгівлю людьми [Електронний ресурс]. Режим доступу: olynpressclub.org.ua.

10. Про Уповноваженого Верховної Ради України з прав людини: Закон України від 02 жовтня 2018 р. № 2581-VIII // Відомості Верховної Ради України. - 2018. - № 46. - Ст. 371.

11. Голосніченко Д. Роль омбудсмена в протидії торгівлі людьми / Д. Голосніченко, В. Стеценко / Протидія незаконній міграції та торгівлі людьми: матеріали II Міжнародного науково-практичного симпозіуму (м. Івано-Франківськ, 16-17 березня 2018 р). - Івано-Франківськ: Редакційно-видавничий відділ Університету Короля Данила. - 2018. - С. 35-38.

Фелонюк Д. Административно-правовые механизмы противодействия торговле людьми в контексте защиты прав и свобод граждан Украины за рубежом. Проанализированы национальный механизм взаимодействия субъектов, которые осуществляют мероприятия по защите прав и свобод граждан Украины за рубежом. Рассматриваются особенности применения понятия «торговля людьми» в праве. Исследуются масштабность проблемы и направления ее решения с учетом европейского опыта. Обращается внимание на необходимость тесной координации действий отечественных и международных организаций по предупреждению и защите граждан Украины от торговли людьми, борьбой с преступностью связанной с этими противоправными действиями. Сделан вывод, что национальный административно-правовой механизм противодействия торговли людьми предусматривает систему мероприятий, направленных на выявление преступления торговли людьми, установление лиц, причастных к его совершению и привлечения их к ответственности. Эффективность данного механизма зависит в значительной степени от взаимодействия и координации действий между национальными и международными институтами, сферой которых является торговля людьми. Этому будет способствовать интеграция украинского законодательства к европейскому а также сотрудничество как государственных так и негосударственных субъектов, осуществляющих мероприятия в сфере противодействия торговле людьми. Требуют согласованных межгосударственных действий процедуры экстрадиции жертв торговли людьми, так как большинство дел завершается в основном их арестом и депортацией. Ощущается нехватка высококвалифицированных работников в системе правоохранительных органов, миграционных служб и других учреждений, в компетенцию которых входит противодействие торговле людьми и оказания помощи пострадавшим от этого преступления. Более результативным в этом плане является сотрудничество международных правозащитных организаций и средств массовой информации.

Ключевые слова: торговля людьми, права, свободы, гражданин Украины.

Feloniuk D. Administrative and Legal Mechanisms for Combating Human Trafficking in the Context of Protecting the Rights and Freedoms of Citizens of Ukraine Abroad. The article elucidates features of the national mechanism of interaction of the subjects carrying out measures to protect the rights and freedoms of the Ukrainian citizens abroad. The basis for the study is the rules of the concept of «human trafficking» interpretation in law. The magnitude of the problem and the directions of its solution are considered, taking into account the European experience. The author argues the need for close coordination of the actions of national and international institutions to prevent this evil, protect the Ukrainian citizens from trafficking, and to combat the crimes associated with these illegal actions. The study findings manifest that the national administrative and legal mechanism for combating human trafficking provides a system of measures to detect the crime of human trafficking, to identify the persons involved in its commission, and how to bring them to justice. The effectiveness of this mechanism, to a large extent, depends on the interaction and coordination of actions between national and international institutions dealing with human trafficking. The facilitating factors are the integration of Ukrainian legislation into European law, the cooperation between state and non-state subjects, participating in combating human trafficking. Procedures for the extradition of victim of human trafficking require concerted internationals actions, as most cases end their arrest and deportation. There is a lack of highly qualified workers in the system of law enforcement agencies, migration services and other institutions, which are responsible for combating human trafficking and providing assistance to victims of this crime. Cooperation between international human rights organizations and the media is more effective in this regard.

Key words: human trafficking, rights, freedoms, citizen, Ukraine. 